\title{
IMPLEMENTASI SISTEM BAGI HASIL PADA PERKEBUNAN KARET RAKYAT MASYARAKAT KABUPATEN KAMPAR RIAU
}

\author{
Oleh : \\ 1. Henni Indrayani, SE, MM \\ 2. Harkaneri, SE,MSA, Ak, CA
}

\begin{abstract}
ABSTRAK
Masyarakat Kampar sudah lama melakukan sistem bagi-hasil di perkebunan karet dengan istilah bagi-hasil gotah. Penelitian ini bertujuan untuk memperoleh pemahaman mendalam tentang penerapan bagi-hasil pada perkebunan karet rakyat masyarakat Kampar Riau (bagi-hasil gotah) dari sudut pandang pelaku yang menghayati kejadian bagi-hasil gotah pada perkebunan karet rakyat Kampar melalui pengamatan yang bersifat partisipatif.

Penelitian ini menggunakan metode kualitatif dengan pendekatan Etnografi.Teknik pengumpulan data dilakukan dengan menggunakan obeservasipartisipasi dan wawancara secara terbuka dan mendalam, Penelitian ini menggunakan model analisis data dari Spradley (1997), meliputi analisis domain, analisis taksonomi, analisis komponensial dan analisis tema kultural.

Hasil studi ini antara lain: Bagi-hasil gotah merupakan bagi-hasil yang merupakan tradisi adat yang diturunkan secara turun-temurun dan bersendikan kepada nilai-nilai syara (agama Islam). Bagi-hasil gotah terbagi atas : bagi duo (1/2 untuk pemilik dan $1 / 2$ untuk tukang motong), bagi tigo ( $1 / 3$ untuk pemilik dan $2 / 3$ untuk tukang motong, bagi ompek ( $1 / 4$ untuk pemilik dan $3 / 4$ untuk tukang motong ) dan bagi limo (2/5 untuk pemilik dan 3/5 untuk tukang motong). Bagi-hasil gotah merupakan bagi-hasil yang unik dimana bagian yang terbesar untuk tukang motong, ini menunjukkan keberpihakan kepada pekerja yang ekonominya lemah. Hal ini sangat berbeda sekali dengan ekonomi kapitalis yang berpihak ke pemilik modal. Harga karet berflutatif sesuai dengan harga pasar internasional. Petani karet tidak mengetahui pergerakan harga pasar ini, semata-mata informasi harga getah yang mereka dapatkan hanya harga dari toke getah. Harga karet yang rendah menjadi permasalahan dalam sistem bagi-hasil karet rakyat, sehingga banyak banyak tukang motong yang berhenti memotong dan mencari pekerjaan lain yang lebih menjanjikan, begitu juga dengan petani karet banyak yang menjual kebun karetnya atau mengubah fungsi kebun karetnya menjadi perkebunan kelapa sawit.

Diharapkan pemerintah untuk lebih memperhatikan petani karet, terutama petani karet rakyat dengan memberikan bantuan bibit unggul, pupuk, modal, pelatihan dan pendidikan tentang perkebunan karet, membentuk kelompok petani dan mengawasi harga karet. Diharapkan petani karet membentuk koperasi atau melakukan kerja sama dengan 10 atau 20 orang petani yang berkomitmen untuk menghasilkan karet putih yang bebas dari kotoran kemudian diantar langsung ke pabrik tanpa melalui tangan ketiga, petani bisa lebih untung karena pabrik mau membeli dengan harga yang lebih tinggi. Lebih dari $80 \%$ dari produksi karet alam Indonesia diekspor dalam bentuk barang mentah, sehingga fluktuasi harga di pasar dunia sangat merugikan petani di dalam negeri. Berbeda jika ekspor dalam bentuk
\end{abstract}


barang jadi seperti ban dan produk karet lainnya yang harganya lebih stabil berbeda dengan barang mentah yang fluktuatif dan rentan dengan aksi para spekulan.

Kata kunci: Bagi-hasil, perkebunan karet, etnografi, bagi-hasil gotah

\section{Pendahuluan}

\subsection{Latar Belakang}

Ruang lingkup profesi yang berkembang di masyarakat dalam kehidupan sehari-hari berbeda-beda, ada yang berprofesi sebagai pedagang, petani, pemilik modal dan lain sebagainya. Profesi sebagai pemilik modal bukanlah merupakan profesi yang dominan dalam masyarakat, karena masih ditemukan profesi lain yang lebih dominan dalam masyarakat seperti petani, buruh lepas, dan pekerja sektor informal lainnya.

Sistem bagi hasil telah lama dipraktikan di perekonomian Indonesia jauh sebelum adanya sistem bagi hasil di lingkungan perbankan. Dalam dunia perbankan bagi hasil dikenal dengan istilah mudharabah sementara dalam perekonomian di masyarakat mengunakan istilah yang berbeda untuk bagi hasil. Sistem bagi hasil ini lahir dari adanya rasa saling membutuhkan antara pemilik modal dengan pengelola modal. Pemilik modal merupakan orang yang kelebihan dalam hal harta kekayaan akan tetapi ia tidak mampu atau berhalangan untuk mengelola harta kekayaannya tersebut. Sementara itu pengelola modal adalah orang yang memiliki kelebihan dalam hal pengelolaan harta kekayaan dan pengembangannya akan tetapi ia tidak memiliki harta kekayaan yang dapat ia kelola, sehingga mendatangkan keuntungan yang diharapkan. Dengan demikian merupakan suatu hal yang sangat tepat dan bijak bila keduanya menyatukan pontensi masing-masing sehingga dapat mewujudkan keuntungan dan kekuatan ekonomi yang produktif (Badri,2009).

Sistem bagi-hasil ini dilakukan dengan tujuan untuk menghindari para petani yang tidak mempunyai modal dari prilaku pinjaman kepada bank-bank konvensional yang menggunakan sistem bunga cenderung kepada riba, serta memberatkan bagi petani untuk membayar hutang apabila terjadinya pinjaman. 
Bagi para petani yang miskin yang berada dalam keadaan yang tidak baik apabila terjadi pinjaman kepada bank konvensional, mereka terpaksa untuk membayar pinjaman hutang mereka meskipun hasil dari perkebunan dan pertanian mereka tidak menjadi atau memperoleh hasil yang sedikit. Namun berbeda halnya dengan sistem bagi-hasil ini, dimana para petani hanya perlu membayar sesuai dengan hasil yang mereka peroleh, baik hasil panennya melimpah maupun sedikit. Dalam persoalan bagi-hasil ini, yang perlu dibayar atau dibagikan antara kedua belah pihak adalah kadar rasio daripada hasil pertanian dan perkebunan yang diperoleh, bukan satu jumlah yang tetap. Ini sejalan dengan apa yag dijelaskan oleh Chapra (2000) bahwa sistem bagi-hasil mempunyai tujuan membangun keadilan dalam pembiayaan kewirausahaan melalui kerjasama kemitraan yang sejajar antara pengusaha dan pemodal.

Provinsi Riau merupakan salah satu daerah di Indonesia yang kaya akan sumber daya alam. Disamping terkenal kaya dengan minyak bumi dan kehutanan, Provinsi Riau juga dikenal memiliki potensi yang besar di bidang perkebunan terutama perkebunan karet dan sawit. Perkebunan karet sudah membudaya dalam kehidupan sehari-hari masyarakat Riau, karena sudah dikenal masyarakat dari zaman dulu. Perkebunan karet-rakyat di Provinsi Riau pada umumnya diusahakan oleh petani dalam skala kecil (sempit) dan dilakukan secara tradisional. Didalam mengelola kebun tersebut ada yang dikelola langsung oleh yang punya kebun dan ada yang dikelola oleh orang lain yang nantinya hasil dari penjualan karet tersebut mereka bagi berdasarkan persentase atau nisbah yang telah mereka sepakati.

Berdasarkan uraian di atas peneliti tertarik melakukan penelitian terhadap sistem bagi hasil pada perkebunan karet rakyat di Kabupaten Kampar Riau, karena pada masyarakat Kampar berkebun karet sudah membudaya dan sudah dilakukan sejak zaman dahulu. Dalam berkebun karet banyak masyarakat yang melakukan sistem bagi-hasil, ini disebabkan sebagian dari pemilik kebun karet ada yang tidak bisa atau tidak sempat mengurus kebun karetnya karena sesuatu hal. Mereka meminta orang lain untuk mengelola atau mengurus kebun karetnya lalu dari hasil penjualan getah/karet tersebut mereka bagi sesuai dengan kesepakatan diantara mereka. 


\subsection{Fokus Penelitian}

Dari uraian latar belakang masalah di atas, maka fokus penelitian ini adalah ingin mengkaji secara mendalam praktik-praktik bagi hasil yang berlaku di kalangan petani karet rakyat di kabupaten Kampar dan mengkaji proses penentuan besaran bagi hasil yang berlaku.

\section{Tinjauan Kepustakaan}

\subsection{Pengertian Sistem Bagi Hasil}

Pengertian bagi hasil secara umum adalah kerja sama antara pemilik dana atau penanam modal dengan pengelola modal atau pelaksana usaha, untuk melakukan usaha tertentu dengan pembagian keuntungan berdasarkan nisbah (berdasarkan prosentase) yang telah disepakati antara pemodal dengan pengelola modal (Purnamasari, 2011:31). Jika terjadi kerugian maka kerugian ini akan ditanggung oleh si pemilik dana/ modal kecuali disebabkan oleh misconduct, negligence atau violation oleh pengelola dana (Nurhayati \& Wasilah, 2009:112).

Bagi-hasil (Mudharabah) secara teknis merupakan akad kerjasama usaha antara dua pihak dimana pihak pertama (shahibul maal) menyediakan seluruh modal, sedangkan pihak lainnya menjadi pengelola. Keuntungan usaha secara mudharabah dibagi menurut kesepakatan yang dituangkan dalam kontrak, sedangkan apabila rugi ditanggung oleh pemilik modal selama kerugian itu bukan akibat kelalaian si pengelola. Jika kerugian itu diakibatkan karena kecurangan atau kelalaian si pengelola, si pengelola harus bertanggung jawab atas kerugian itu (Asy Syarbasi, dikutip dalam Antonio, 2001).

Menurut Rahmat (2005) bagi hasil (mudharabah) adalah suatu kontrak kemitraan (partnership) yang berlandaskan pada prinsip pembagian hasil, dengan cara seseorang memberikan modalnya kepada yang lain untuk melakukan bisnis dan kedua belah pihak membagi keuntungan atau memikul beban kerugian berdasarkan isi perjanji an bersama. Pihak pertama, supplier atau pemilik modal disebut mudharib dan pihak kedua, pemakai atau pengelola atau penguasa disebut dharib. Oleh karena itu bagi-hasil merupakan kemitraan antara penyumbang modal pada satu pihak dan pemakai modal di pihak lainnya. Selanjutnya Rahmat (2005) menyatakan bahwa dalam mudharabah, pihak yang menyediakan barang dagangan dan pihak yang menjalankan usaha tersebut bisa saja terdiri dari beberapa orang, misalnya modal bisa saja disediakan oleh beberapa orang dan usaha tersebut dijalankan beberapa orang lainnya. 
Kemungkinan lainnya, boleh juga modal berasal dari satu orang dan pihak yang memanfaatkannya beberapa orang atau beberapa orang menyatukan modal mereka, kemudian seseorang memanfaatkannya untuk menjalankan usaha. Mudharib memberikan modalnva kepada dharib dan sebagai imbalannya ia memperoleh bagian tertentu dari keuntungan yang diperoleh, tetapi apabila mengalami kerugian, beban seluruhnya ditanggung oleh mudharib dan (dharib) tidak menerima apa-apa atas jasa yang telah ia lakukan.

Ciri khas dari bagi-hasil adalah saling percaya yang tinggi antar kedua belah pihak yaitu antara pemilik dana/modal (shahibul maal) dengan pengelola dana/modal (mudharib). Oleh sebab itu bagi-hasil sebagai akad investasi yang beresiko tinggi karena dapat menimbulkan masalah asymmetric information dan moral hazard (Nurhayati \& Wasilah, 2009:112).

\section{Metodologi Penelitian}

\subsection{Etnografi sebagai Pendekatan Penelitian}

Etnografi merupakan salah satu metode penelitian kualitatif. Etnografi digunakan untuk meneliti perilaku-perilaku manusia berkaitan dengan sosial dan budaya tertentu. Metode penelitian etnografi dianggap mampu menggali informasi secara mendalam dengan sumber-sumber yang luas. Dengan teknik "observatory participant", etnografi menjadi sebuah metode penelitian yang unik karena mengharuskan partisipasi peneliti secara langsung dalam sebuah masyarakat atau komunitas sosial tertentu.

Untuk mengetahui bagaimana masyarakat melakukan sistem bagi-hasil pada perkebunan karet rakyat Kampar, maka pendekatan yang digunakan dalam penelitian ini adalah pendekatan etnografi, karena dalam penelitian ini ingin menjelaskan bagaimana suatu masyarakat dalam mengeksplorasi keyakinan, perilaku, pengalaman, sistem nilai dan norma dalam masyarakat Kampar Riau.

\section{Objek Penelitian}

Penelitian ini dilakukan untuk mengungkap "praktik bagi-hasil" dalam perkebunan karet rakyat masyarakat Kabupaten Kampar Provinsi Riau.

Oleh karena itu untuk memperoleh gambaran bagaimana sistem bagi-hasil pada perkebunan karet rakyat Kampar secara holistic menurut masyarakat Kampar 
Riau maka pemilihan objek praktik bagi-hasil pada kebun karet rakyat masyarakat Kampar dirasa tepat.

\section{Lokasi Penelitian}

Penelitian ini di lakukan di empat kecamatan yang ada di kabupaten Kampar yang mempunyai kebun karet yang luas yaitu : Kecamatan Bangkinang, kecamatan Kuok, kecamatan 13 Koto Kampar dan kecamatan Kampar Kiri. Kedekatan peneliti dengan lokasi penelitian memungkinkankan peneliti memahami tentang situasi sosial dan budaya yang memudahkan dalam kelancaran proses penelitian ini.

\subsection{Informan dan Kehadiran Peneliti}

Dalam menentukan jumlah informan bukan menjadi pertimbangan utama, tetapi yang dibutuhkan adalah pertimbangan kualitas informasi yang didapat dan keterwakilan kasus. Untuk menentukan dan mendapatkan informan agar dapat menggali berbagai informasi diperlukan informan pendukung seperti pemuka masyarakat, pemilik kebun, penyadap karet dan toke.

\subsection{Sumber Data dan Metode Pengumpulan Data}

Menurut Lofland dan Lofland (1987) dalam Moleong (2005) sumber data utama dalam penelitian kualitatif adalah 1) kata-kata, dan 2) tindakan, sedangkan data lain seperti dokumen pribadi, dokumen resmi, sumber buku, arsip dan majalah ilmiah hanya merupakan data tambahan.

Metode pengumpulan data yang dipergunakan adalah melalui pengamatan dan wawancara dengan informan. Informan yang dijadikan sebagai sumber informasi dalam penelitian ini terbagi atas; masyarakat Kampar yang terlibat dalam sistem bagi-hasil baik pemilik kebun karet maupun pengarap kebun, toke (penadah hasil kebun karet) dan tokoh masyarakat Kampar.

Informan yang diwawancarai adalah yang memiliki pengetahuan yang cukup serta mampu menjelaskan keadaan sebenarnya tentang objek penelitian. Wawancara lebih banyak dilakukan secara informal, hal ini dilakukan agar informasi yang diberikan oleh informan benar-benar akurat. Untuk mempermudah merekam hasil informasi dengan dialog informan, peneliti membuat catatan harian untuk mencatat kata-kata kunci yang merupakan data atau fakta yang dianggap dapat menjelaskan permasalahan penelitian. 


\subsection{Teknik Analisis dan Keabsahan Data}

Pada penelitian ini alur metodologi dimulai dari pengumpulan data, baik dengan studi dokumentasi, wawancara, dan observasi. Setelah data dikumpulkan baru kemudian direduksi dengan menghilangkan hasil wawancara yang diluar konteks pertanyaan. Langkah berikutnya adalah penyajian data, dengan cara teks naratif dengan tujuan memudahkan memberikan kesimpulan.

Kedua melalui triangulasi yang digunakan untuk menguji derajat kepercayan. Triangulasi diartikan sebagai pengecekan data dari berbagai sumber dengan berbagai cara dan berbagai waktu. Sehingga terdapat triangulasi sumber, triangulasi teknik pengumpul data dan triangulasi waktu (Sugiyono, 2010).

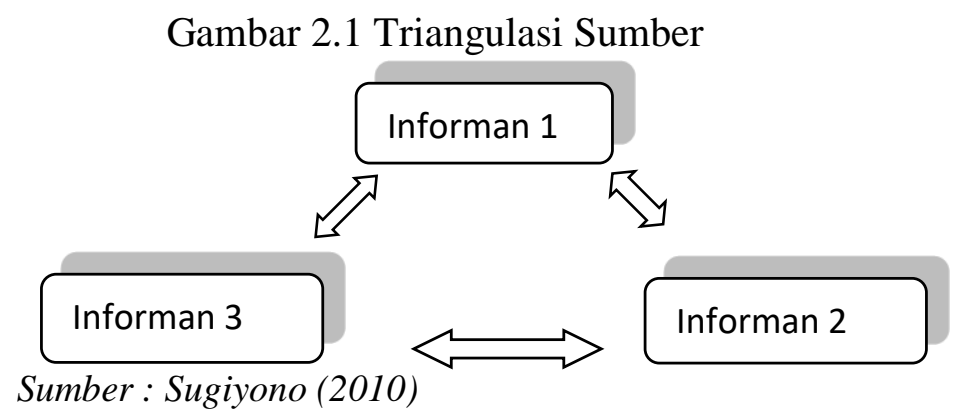

Gambar 2.2. Triangulasi Teknik

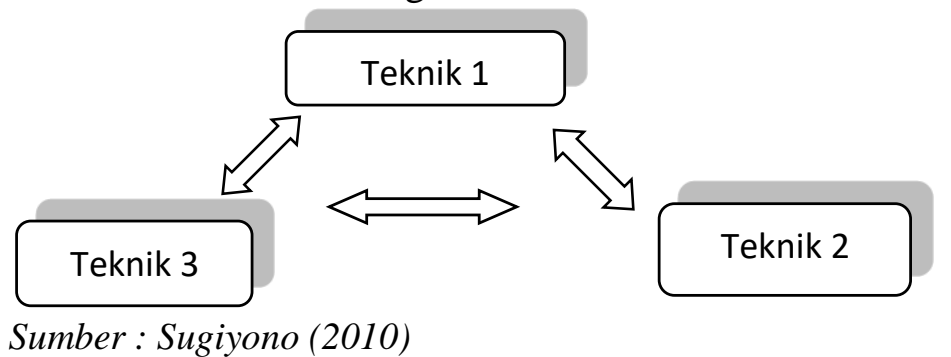

Gambar 2.3. Triangulasi Waktu

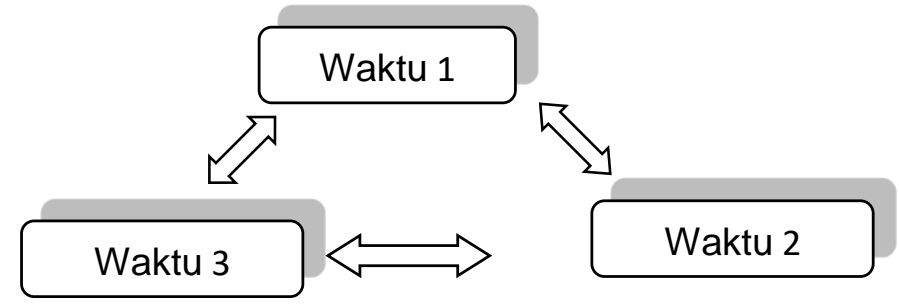

Sumber : Sugiyono (2010)

\section{Hasil Penelitian dan Pembahasan}

4.1. Perkebunan Karet Rakyat Masyarakat Kampar Sebagai Tumpuan Kesejahteraan 
Perkebunan karet memberikan peranan penting bagi perekonomian nasional yaitu sebagai sumber devisa, sumber bahan baku industri, sumber pendapatan dan kesejahteraan masyarakat serta sebagai pegembangan pusat-pusat pertumbuhan perekonomian di daerah dan sekaligus berperan dalam pelestarian fungsi lingkungan hidup.

Bila kita mengunjungi wilayah-wilayah sentral penanaman karet di Riau seperti Kabupaten Kampar, kita melihat bagaimana tanaman ini telah melesap ke dalam darah-daging warga sekitar. Kehidupan sehari-hari petani karet sangat ditentukan oleh naik-turunnya harga komoditas tanaman tersebut yang bisa terjadi sewaktu-waktu.

Dari penjelasan bapak Zulkifli ini dapat kita ketahui bahwa ekonomi masyarakat petani karet sangat tergantung kepada hasil penjualan karet, jika harga karet naik, maka ekonomi mereka naik karena pendapatan mereka dari hasil penjualan karet meningkat sehingga daya beli mereka pun meningkat. Begitu juga sebaliknya jika harga karet turun maka pendapatan mereka dari hasil penjualan karet menurun sehingga daya beli mereka pun menurun.

\subsection{Menelusuri Jejak Sejarah Karet di Kampar}

Jika kita menelusuri jejak sejarah karet di Propinsi Riau umumnya dan Kampar khususnya, maka tidak terlepas dari sejarah karet dunia. Perkembangan Perkebunan Karet di Indonesia dipicu oleh krisis tembakau dan kopi yang menjadi komoditas andalan pemerintah kolonial Hindia Belanda. Krisis ini mendorong pemerintah Hindia Belanda untuk membangun perkebunan karet. Di Indonesia Pemerintah Hindia Belanda untuk pertama kalinya memperkenalkan sistem perkebunan besar (modern) yang dibuka di daerah Indragiri Riau pada tahun 1893.

Dari penjelasan Pak Muslim dapat kita ketahui bahwa masyarakat Kampar dulu membawa dan menjual hasil kebun karetnya ke Malaysia dan Singapura. Hal ini terjadi karena letak strategis Propinsi Riau yang berhadapan langsung dengan Malaysia dan Singapura. Mereka hanya tinggal menyeberang selat Melaka untuk sampai ke Malaysia atau ke Singapura. Pedagang yang membeli hasil kebun karet mereka di kenal sebagai "toke gotah". Selain menjual karet ke sana masyarakat 
juga membeli bibit karet, pupuk dan obat-obatan untuk tanaman karet. Mereka juga membeli barang-barang lainnya disana, karena selat Melaka merupakan jalur perdagangan Internasional sejak dulunya sampai sekarang.

Menurut informan Pak Anas Jas pemerintah Hindia Belanda sangat mendukung perkebunan karet di Riau dengan memberikan bantuan kepada masyarakat dan membiayai perkebunan karet rakyat. Akan tetapi masyarakat harus menjual ke Pemerintahan Hindia Belanda dengan harga dan pajak yang sudah ditentukan oleh Pemerintah Hindia Belanda yang nantinya akan diekspor ke luar negeri oleh Pemerintah Hindia Belanda. Berikut pernyataan Bapak Anas Jas:

"Sementara itu menurut pegawai Dinas Perkebunan Provinsi Riau bapak Sd Bstm menyatakan bahwa pemerintah sudah lama memperhatikan perkebunan karet di Riau, karena Riau merupakan Provinsi yang terbesar menghasilkan karet sejak zaman dulu, berikut penjelasan beliau tentang sejarah perkebunan karet di Riau yang dibina Dinas Perkebunan:

Sejarah perkebunan sejak tahun 1956 itu dilaksanakan jawatan karet di daerah dan di biayai oleh pemerintah pusat. Pada tahun 1959 karet dilaksanakan oleh dinas pertanian karet. Kemudian tahun 1972 lahirlah Dinas Perkebunan Rakyat. Karet dilaksanakan oleh pemerintah pusat dan pemerintah daerah. Pengembangan karet terus di kembangkan oleh Mantri Perkebunan Kecamatan sebagai penyuluh perkebunan di tingkat kecamatan sampai 1980.

Pertengahan 1980 dibentuk UPP (Unit Pelaksanaan Perkebunan) diseluruh Riau GCC (Group Coalition Center). Di Propinsi Riau ada 18 UPP karet yang selanjutnya oleh pemerintah pusat dibantu dengan proyek karet rakyat TCSDP ( Tree Cogulation Small Development Project). Untuk pembangunan perkaretan oleh pemerintah pusat dilengkapi dengan bantuan alat pengolahan hasil produksi Bank Dunia yang diberikan program STCPP (Small Holder Tree Crops Product Project) yang mendapat alokasi 1000 unit pada 6 kabupaten yaitu Kampar, Bengkalis, Indragiri Hulu, Indragiri Hilir, Kepulauan Riau dan Dumai. 
Sesudah itu baru karet dikembangkan dengan pola PIR (Perkebunan Inti Rakyat) pada tahun 1986. PIR ada 5 yaitu :

1. PIR Lokal untuk masyarakat tempatan

2. PIR Khusus untuk trasmigran atau lokal.

3. PIR Transmigrasi untuk transmigrasi

4. PIR NES (Neclues Estate Small Holder) yang merupakan percobaan perkebunan karet di Riau.

5. PIR KKPA (Kredit Koperasi Primer anggota.

Dari tahun 2008 sampai kini dibiayai dengan dana APBN dan APBD dengan secara parsial.

Dari penjelasan Bapak Sd Bstm dapat kita ketahui bahwa sejak tahun 1956 pemerintah mulai memperhatikan perkebunan karet di Riau yang dibiayai oleh pemerintah pusat. Dinas Perkebunan Rakyat berdiri tahun 1972 dimana karet dilaksanakan oleh pemerintah pusat dan pemerintah daerah. Kemudian pada tahun 2008 sampai sekarang karet dibiayai dengan dana APBN dan APBD secara parsial.

\subsection{Perkebunan Karet Tradisi Masyarakat Kampar}

Perkebunan karet pada masyarakat Kampar merupakan tradisi budaya yang dipelihara secara turun-temurun sejak zaman dulu, sehingga jual-beli karet sangat mempengaruhi ekonomi dan sosial masyarakat Kampar. Salah satu bukti pengaruh dari perkebunan karet ini dapat kita lihat pada penetapan hari pasar pada masyarakat Kampar dimana hari pasar ditetapkan pada hari setelah terjadinya jual-beli karet. Dan ini terus berlangsung sampai sekarang. Dengan demikian tanaman karet ini sangat mempengaruhi ekonomi dan sosial masyarakat Kampar.

\subsubsection{Tradisi Bagi-Hasil Yang Tidak Bertentangan Syara}

Tradisi bagi-hasil merupakan tradisi yang dipelihara secara turuntemurun oleh masyarakat Kampar dalam berkebun karet. Apalagi bagi-hasil ini tidak bertentangan dengan ajaran Islam yang merupakan agama mayoritas penduduk Riau khususnya masyarakat Kampar.

\subsubsection{Kebun Karet Simbol Kekayaan Masyarakat Kampar}


Bagi-hasil terjadi karena adanya pihak-pihak yang saling membutuhkan. Begitu juga dengan bagi-hasil pada perkebunan karet rakyat masyarakat Kampar. Perjanjian bagi-hasil di kebun karet biasanya terjadi pada pemilik kebun karet yang memiliki kelebihan ekonomi. Dalam masyarakat Kampar kebun karet merupakan simbol kekayaan.

Dari penjelasan bapak Nasir diatas dapat kita ketahui bahwa kebun karet merupakan simbol kekayaan masyarakat Kampar. Pemilik kebun karet ini pada umumnya merupakan orang yang memiliki kelebihan ekonomi (kaya). Selain itu pemilik kebun biasanya juga memiliki mata pencaharian tetap diluar berkebun karet seperti pedagang atau pegawai sehingga waktu mereka untuk memelihara kebun karet mereka tidak ada.

\subsection{Proses Perjanjian Bagi-Hasil Kebun Karet di Kabupaten Kampar}

\subsubsection{Perjanjian yang Berlandaskan Kepercayaan Penuh}

Proses terjadinya bagi-hasil kebun karet masyarakat Kampar bermula dari salah satu pihak mendatangi pihak yang lainnya. Ada tukang motong yang datang ke rumah orang pemilik kebun untuk meminta agar dia yang menjadi tukang motong dikebun karet orang itu. Jika pemilik kebun setuju, maka pemilik kebun dan tukang motong pergi melihat kebun karet. Setelah ditunjukkan kebun karet dan batas-batas kebunnya, maka kedua belah pihak membuat kesepakatan bagi-hasil berdasarkan keadaan kebun karet tersebut.

Namun ada juga orang yang punya kebun karet yang mencari tukang motong untuk membantunya dalam mengambil hasil panen kebun karetnya. Apalagi jika pemilik kebun karet itu tinggal jauh dari kebun karetnya.

Ciri khas bagi-hasil adalah kepercayaan penuh, begitu juga dengan bagihasil di perkebunan karet rakyat masyarakat Kampar. Pemilik kebun karet memberikan kepercayaan yang tinggi kepada tukang motong gotah untuk mengambil hasil getah kebunnya. Apalagi perjanjian ini menurut tukang motong bapak Syafrizal dan bapak Makmur biasanya hanya dengan muluk saja (perjanjian tidak tertulis), jarang sekali perjanjian di atas kertas. 


\subsubsection{Bagi-Hasil Yang Mengharapkan Kejujuran dan Kepasrahan Kepada Tuhan}

Kejujuran tukang motong sangat menentukan dan mempengaruhi bagi kalangsungan dari sistem bagi-hasil perkebunan karet masyarakat Kampar. Karena pemilik kebun sudah memberikan kepercayaan penuh kepada tukang motong dengan melihat kemampuan tukang motong dalam mengelola kebun karet secara maksimal sesuai perjanjian bagi-hasil, serta memberikan informasi yang sejujurnya tentang besar atau kecilnya jumlah pendapatan yang diperoleh per minggunya atau pada suatu periode tertentu tanpa ada sedikitpun unsur manipulasi untuk mengurangi nilai nominal dari pendapatan penjualan karet yang diperolehnya.

Untuk menimalisir terjadinya manipulasi data penjualan karet ada kalanya pemilik kebun yang datang melihat kebun karetnya sekali seminggu terutama pada waktu penjualan karet.

\subsubsection{Proses Bagi-Hasil Perkebunan Karet Rakyat Masyarakat} Kampar

Proses perjanjian bagi-hasil di kebun karet masyarakat Kampar di mulai dari adanya kesepakatan antara pemilik kebun dengan penderes (tukang motong) dimana pemilik kebun menyerahkan dan mempercayakan kebun karetnya kepada tukang motong, sementara tukang motong bekerja mengambil hasil panen getah dan melaporkan secara jujur hasil penjualan karet kepada pemilik karet. Kemudian dari hasil penjualan karet tadi mereka bagi berdasarkan kesepakatan mereka. Selain itu dari hasil wawancara dengan informan serta dari hasil pengamatan di lapangan dapat diketahui bahwa :

1. Subjek perjanjian bagi-hasil gotah adalah pelaku bagi-hasil yakni pemilik kebun dan tukang motong gotah. Berdasarkan hasil pengamatan tidak ada ditemukan pihak yang berbentuk badan hukum. Mereka terdiri dari individu-individu yang memiliki kepentingan untuk meningkatkan kesejahteraan mereka. Pelaku bagi-hasil harus cakap hukum dan baligh.

2. Objek perjanjian bagi-hasil gotah adalah tanaman karet dan kerja dari tukang motong. Kebun karet yang diserahkan harus jelas luasnya serta jelas 
batas-batas kebun karet tersebut. Kontribusi tukang motong adalah berbentuk keahlian dan ketrampilannya dalam menyadap karet.

3. Adanya serah terima dari pemilik kebun ke tukang motong gotah biasanya merupakan pernyataan secara lisan. Selain itu kedua belah pihak saling ridha atau rela dalam menerima perjanjian bagi-hasil tersebut

4. Adanya pembagian keuntungan antara pemilik kebun dengan tukang motong yang disesuaikan dengan keadaan kebun karet serta dengan mempertimbangan hak dan kewajiban masing-masing pihak. Besarnya bagian mencerminkan imbalan yang berhak diterima oleh kedua belah pihak atas pendapatan dari penjualan karet yang diperoleh. Tukang motong mendapat imbalan atas kerjanya, sedangkan pemilik kebun mendapat imbalan atas kebun karetnya. Besarnya bagian bagi hasil harus diketahui dengan jelas oleh kedua belah pihak dan disetujui oleh kedua belah pihak. Hal ini untuk mencegah terjadinya perselisihan antara kedua belah pihak. Pemilik kebun tidak boleh meminta pembagiannya bagi-hasil karet dengan menyatakan nilai nominal tertentu atau menetapkan uang dalam jumlah tertentu, akan tetapi pembagian harus dalam bentuk prosentase (\%) bagian masing-masing pihak seperti bagi duo (1/2:1/2), bagi tigo (1/3:2/3 atau bagi limo $(2 / 5: 3 / 5)$.

Lamanya kerjasama dalam bagi-hasil ini tidak tentu dan tidak terbatas, tetapi semua pihak berhak untuk menentukan jangka waktu perjanjian kerja sama dengan memberitahukan pihak lainnya seperti :

1. Salah satu pihak memutuskan berakhirnya kerja sama.

2. Salah satu pihak meninggal dunia.

3. Tukang motong tidak menjalankan amanahnya untuk mencapai tujuan kedua belah pihak sebagaimana yang sudah disepakati bersama. Karena tukang motong harus mengemban kepercayaan yang sudah diberikan kepadanya, ia harus jujur dalam melaporkan hasil pendapatan penjualan karet. Dan dalam melakukan penyadapan karet ia harus mengikuti aturan yang sudah mereka sepakati bersama. 
4. Kebun karet sudah tidak ada akibat suatu bencana seperti kebakaran dan lain-lain.

Skema Bagi-Hasil Perkebunan Karet Rakyat Kampar

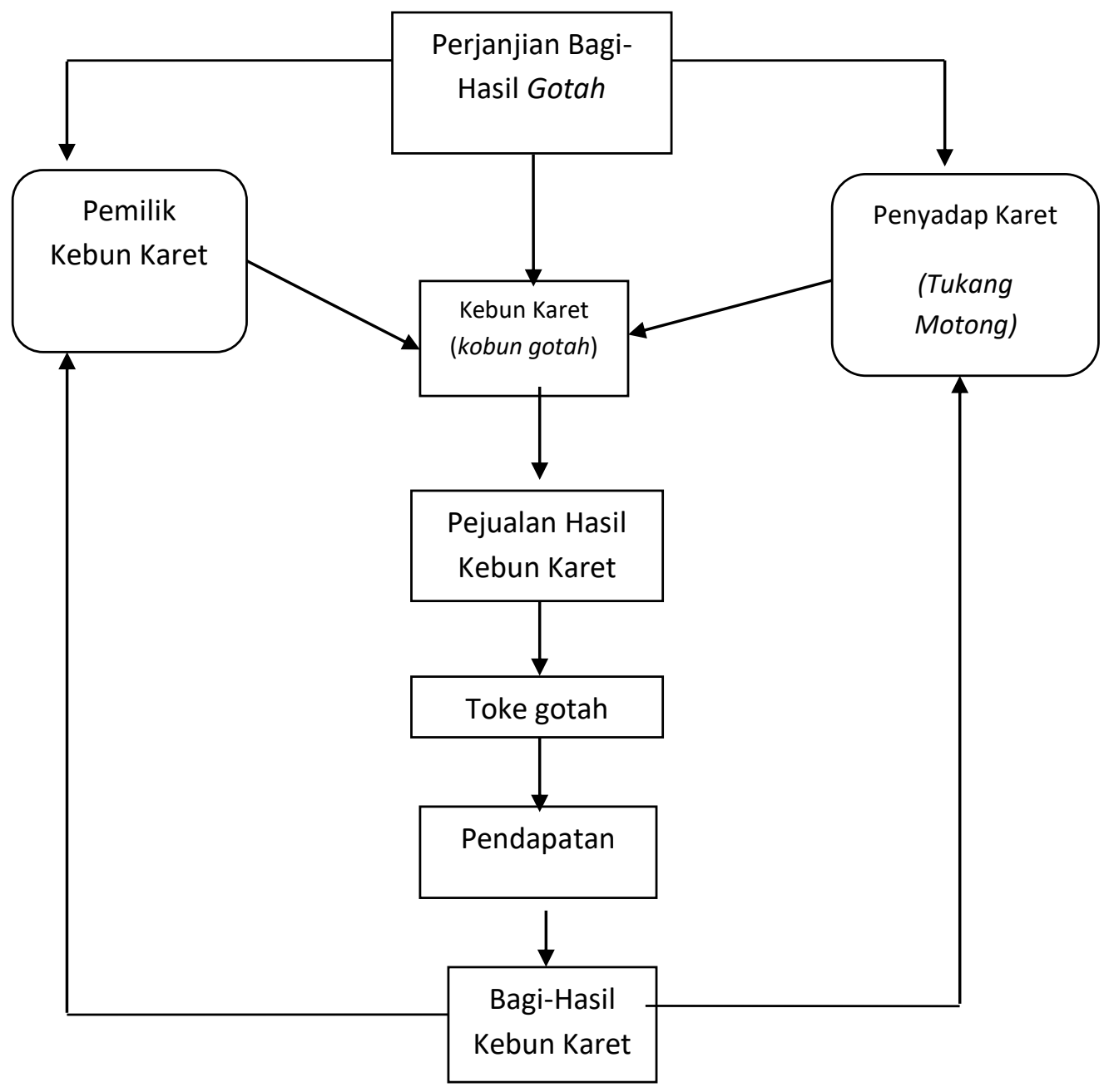

Keterangan :

1. Pemilik kebun dan tukang motong menyepakati perjanjian bagi-hasil kebun karet.

2. Pemilik kebun menyerahkan asset kebun karetnya kepada tukang motong (penyadap karet). Sementara tukang motong mengelola atau mengambil hasil kebun karet dengan tenaga dan skill yang dimilikinya. 
3. Hasil kebun karet dijual oleh tukang motong ke toke gotah, biasanya sekali seminggu sebelum hari pasar di daerah tersebut.

4. Dari hasil penjualan gotah karet diperoleh pendapatan, Toke gotah mencatat di kertas kecil yang didalamnya menjelaskan tentang banyaknya hasil karet $(\mathrm{kg})$, harga karet pada saat itu yang mana pendapatan ini di laporkan ke pemilik kebun sesuai dengan catatan yang dibuat oleh toke.

5. Kemudian dari hasil pendapatan inilah dibagi sesuai dengan kesepakatan mereka diawal perjanjian.

\subsection{POLA BAGI-HASIL DI PERKEBUNAN KARET RAKYAT}

MASYARAKAT KAMPAR

Tabel Pola Bagi-hasil Hasil Berdasarkan Kesepakatan Antara Pemilik Dan

Pekerja

\begin{tabular}{|c|c|c|c|}
\hline Jenis-Jenis & Pemilik & Pekerja & Ketentuan/ Kriteria \\
Bagi Hasil & (Punyo & (Tukang & \\
(Tergantung & Kobun) & Motong) & \\
Kesepakatan) & & & \\
\hline
\end{tabular}




\begin{tabular}{|c|c|c|c|}
\hline Bagi Dua & $1 / 2$ & $1 / 2$ & $\begin{array}{l}\text { 1. Hanya sebagai pengambil hasil atau } \\
\text { sebagai pemotong, Tukang Motong } \\
\text { tidak berkewajiban membersihkan } \\
\text { lahan } \\
\text { 2. Pisau Gotah, Cuko, dan Ember serta } \\
\text { peralatan lainnya ditanggung oleh } \\
\text { Pemilik (Punyo Kobun) } \\
\text { 3. Tergantung Jarak, jauh dekatnya lokasi } \\
\text { lahan dari pemukiman penduduk, } \\
\text { ketentuan pembagian ini berlaku kalau } \\
\text { jaraknya dekat. } \\
\text { 4. Umur Karetnya masih muda dan air } \\
\text { karetnya masih banyak }\end{array}$ \\
\hline $\begin{array}{l}\text { Bagi Tiga } \\
\text { Bagi Empat } \\
\text { Bagi Lima }\end{array}$ & $\begin{array}{l}1 / 3 \\
1 / 4 \\
2 / 5\end{array}$ & $\begin{array}{l}2 / 3 \\
3 / 4 \\
3 / 5\end{array}$ & $\begin{array}{l}\text { 1. Ada Kewajiban Tukang Motong } \\
\text { mengambil hasil dan membersihkan } \\
\text { lahan. Membersihkan lahan dilakukan } \\
\text { secara bertahap misalnya seluas } 20 \mathrm{x} \\
40 \text { pada tahap I dan seterusnya. } \\
\text { 2. Pisau Gotah, Cuko, dan Ember serta } \\
\text { peralatan lainnya ditanggung oleh } \\
\text { Pekerja (Tukang Motong) } \\
\text { 3. Tergantung Jarak, jauh dekatnya lokasi } \\
\text { lahan dari pemukiman penduduk, } \\
\text { ketentuan pembagian ini berlaku kalau } \\
\text { jaraknya jauh. } \\
\text { 4. Umur Karetnya sudah tua dan air } \\
\text { karetnya sedikit. }\end{array}$ \\
\hline
\end{tabular}

\subsection{Alasan Masyarakat Kampar Mempertahankan Sistem Bagi-hasil di \\ Perkebunan Karet}

1. Sistem bagi-hasil di kebun karet menurut informan sudah menjadi tradisi di Kampar.

2. Masyarakat Kampar tidak memakai sistem upah karena dinilai kurang rasa sosialnya dan kurang tolong-menolong dalam sistem upah tersebut.

3. Jika dipakai sistem upah tukang motong dan pemilik kebun tidak mau karena mereka merasa dirugikan. 
4. Sistem bagi-hasil hasil panen maksimal diperoleh, ini disebabkan oleh karena tukang motong betul-betul berusaha agar hasil sadapannya banyak, karena dengan semakin banyak hasilnya tentu semakin banyak pula ia mendapat, karena persentasenya untuk dia. Berbeda dengan sistem upah harian dimana tukang motong diupah perharinya, tukang motong tidak termotivasi untuk bekerja lebih giat dan tekun, karena hasil dari sadapan tidak berpengaruh kepada pendapatannya, sedikit atau banyak hasil sadapannya pendapatan tukang motong tetap sama.

Jadi keuntungan dalam bagi-hasil ini adalah keuntungan bagi semua pihak baik pihak pemilik maupun pihak pekerja mereka sama-sama diuntungkan atau samo-samo sonang, samo-samo susah.

\subsection{Pertanggungjawaban Tukang Motong}

\subsubsection{Amanah Pemilik Kebun yang Harus Dipertanggungjawabkan Tukang Motong}

Pertanggung jawaban atau akuntabilitas (accountability) merupakan konsep yang tidak asing lagi pada masyarakat Kampar. Pertanggungjawaban selalu berkaitan degan konsep amanah. Amanah merupakan sesuatu yang dipercayakan kepada orang lain untuk digunakan sebagaimana mestinya sesuai dengan yang diinginkan oleh yang memberikan amanah.

Pada perjanjian bagi-hasil ini pemilik kebun karet memberikan amanahnya kepada tukang motong untuk mengelola, menjual hasil kebun dan melaporkan pendapatan dari hasil penjualan getah kebun karetnya dengan jujur, sehingga menghasilkan pendapatan dan kesejahteraan bagi kedua belah pihak. Kejujuran tukang motong dalam melaporkan hasil pendapatan dari kebun karet ini sangat penting sekali. Apalagi jika pemilik kebun tidak pernah mengontrol kebun karetnya dan tidak tahu-menahu dengan keadaan kebun karetnya

Dalam perjanjian ini ditentukan aturan-aturan yang mengikat kedua belah pihak dan menentukan hak dan kewajiban masing-masing sesuai dengan 
keuntungan yang mereka peroleh. Dalam melakukan penyadapan karet tukang motong harus mematuhi aturan-aturan yang sudah mereka sepakati bersama, biasanya aturan ini memuat larangan-larangan yang harus dipatuhi tukang motong agar tanaman karet tidak rusak dan cepat mati. Hal ini bertujuan untuk kelestarian dan pemeliharaan terhadap tanaman karet yang merupakan sumber pendapatan bagi mereka. Jadi mereka tidak memporsir tanaman karet sehingga hasil getahnya banyak yang berdampak pada meningkatnya pendapatan mereka. Akan tetapi mereka menyadap karet secara alamiah dan secara tradisional sehingga kelestarian alam tetap terjaga.

\subsubsection{Catatan Dari Toke Sebagai Bukti Transaksi Penjualan Getah Karet}

Dalam mempertanggung jawabkan amanah yang diberikan oleh pemilik kebun kepadanya, tukang motong melaksanakan kewajibannya sesuai dengan kesepakatan yang sudah mereka sepakati bersama. Selain itu tukang motong juga berkewajiban untuk melaporkan setiap hasil penjualan karet. Penjualan karet dilakukan oleh petani sekali seminggu, yakni sehari sebelum hari pasar di daerah mereka.

Berdasarkan hasil pengamatan di lapangan untuk di daerah Kabupaten Kampar terutama daerah Bangkinang dan sekitarnya transaksi jual-beli getah karet ini terjadi di areal perkebunan karet rakyat. Biasanya yang membeli karet ini adalah penadah karet yang biasa disebut dengan toke gotah. Toke gotah ini mendatangi kebun karet dengan membawa timbangan besi yang digantung atau disebut "dacing".

Dari bukti catatan dari toke gotah dapat kita ketahui bahwa pencatatannya dilakukan dengan cara yang masih sangat sederhana. Dalam sistem bagi-hasil ini tidak ada pencatatan yang baku, karena dalam sistem bagi-hasil ini dilakukan atas dasar saling mempercayai dan atas dasar kekeluargaan. Dasar pembagian pendapatan (Revenue Sharing) tersebut adalah catatan dari toke (penadah hasil kebun) yang berisi tentang berapa banyak berat karet/getah yang dijual, berapa harga per kg-nya pada saat itu dan berapa total penjualannya kemudian dari pendapatan tersebut mereka bagi sesuai dengan kesepakatan mereka pada waktu 
melakukan perjanjian kerjasama (akad) pertama kalinya atau disebut dengan nisbah. Catatan tersebut merupakan alat komunikasi antara pemilik kebun dengan tukang motong untuk mengambil keputusan ekonomi atau kita kenal sebagai akuntansi.

Hambatan yang terdapat dalam bagi-hasil gotah masyarakat Kampar.

1. Petani karet di dalam memanen hasil karet selalu bergantung kepada keadaan cuaca. Pada musim hujan petani tidak bisa menyadap hasil karet sehingga produksi karet menurun. Sedangkan pada musim panas pohon karet akan seperti rontok sehingga susu getah kering. Biasanya 1 kali dalam 6 bulan, dalam keadaan seperti itu pohon karet tidak bisa sadap karena dapat menyebabkan kerusakan pohon karet.

2. Harga. Harga karet berflutatif sesuai dengan harga pasar internasional. Petani karet tidak mengetahui pergerakan harga pasar ini, semata-mata informasi getah yang mereka dapatkan hanya harga getah dari toke getah.

3. Modal tidak cukup

4. Berhutang dengan toke, sehingga mereka terikat dengan toke tersebut.

5. Tidak terorganisirnya petani karet rakyat, sehinngga kedudukan mereka lemah.

6. Masih terbatasnya Peran dinas terkait dalam memajukan pertanian karet rakyat

7. Masih kurangnya pengetahuan petani karet. Petani punya kebiasaan mencampur lateks dengan kotoran/sampah sebenarnya kebiasaan ini malah merugikan petani karena harga jual jadi lebih rendah

8. Lebih dari $80 \%$ dari produksi karet alam Indonesia diekspor dalam bentuk barang mentah, sehingga fluktuasi harga di pasar dunia sangat merugikan petani di dalam negeri. Berbeda jika ekspor dalam bentuk barang jadi seperti ban dan produk karet lainnya yang harganya lebih stabil berbeda dengan barang mentah yang fluktuatif dan rentan dengan aksi para spekulan.

V. Kesimpulan dan Saran

1. Kesimpulan

Karet dalam bahasa Kampar di sebut dengan istilah gotah. Oleh karena itu masyarakat Kampar menyebut bagi-hasil pada perkebunan karet dengan istilah bagi-hasil gotah. Sementara orang yang bekerja mengambil getah karet disebut sebagai tukang motong. 
Bagi-hasil gotah pada masyarakat Kampar ini sudah merupakan tradisi yang diturun-temurunkan sampai sekarang. Jadi bagi-hasil gotah ini sudah membudaya pada masyarakat Kampar.

Bagi-hasil terjadi karena adanya pihak-pihak yang saling membutuhkan. Begitu juga dengan bagi-hasil pada perkebunan karet rakyat masyarakat Kampar ini terjadi karena antara pemilik kebun karet dengan tukang motong saling membutuhkan. Kedudukan kedua pihak sama karena mereka merupakan mitra dalam berusaha. Oleh sebab itu dalam menentukan pola bagi-hasil ini ditentukan dan disepakati oleh kedua belah pihak.

Masyarakat Kampar sudah lama melakukan sistem bagi-hasil di perkebunan karet dengan istilah bagi duo (1/2 untuk pemilik dan 1/2 untuk tukang motong), bagi tigo (1/3 untuk pemilik dan 2/3 untuk tukang motong, dan bagi limo (2/5 untuk pemilik dan 3/5 untuk tukang motong).

Harga karet yang rendah menjadi permasalahan dalam sistem bagi-hasil karet rakyat, sehingga banyak banyak tukang motong yang berhenti memotong dan mencari pekerjaan lain yang lebih menjanjikan, begitu juga dengan petani karet banyak yang menjual kebun karetnya atau mengubah fungsi kebun karetnya menjadi perkebunan kelapa sawit.

2. Saran

Diharapkan pemerintah untuk lebih memperhatikan petani karet, terutama petani karet rakyat dengan memberikan bantuan bibit unggul, pupuk, modal, pelatihan dan pendidikan tentang perkebunan karet, membentuk kelompok petani dan mengawasi harga karet.

Sebenarnya petani bisa menjual lateks dengan harga yang lebih tinggi, dengan membuat kesepakatan atau koperasi bersama 10 atau 20 orang petani yang berkomitmen untuk menghasilkan karet putih yang bebas dari kotoran kemudian antar langsung ke pabrik tanpa melalui tangan ketiga, petani bisa lebih untung karena pabrik mau membeli dengan harga yang lebih tinggi 
Daftar Pustaka

\section{DAFTAR PUSTAKA}

Al-Qur'an dan terjemahan

Alma, Buchari \& Priansa, Donni Juni.2009.Manajemen Bisnis Syariah. Penerbit Alfabeta. Bandung.

Antonio,Muhammad Syafi'i.2001. Bank Syariah Dari Teori ke Praktek.Gema Insani. Jakarta.

Badri, Muhammad Arifin.2009. Riba \& Tinjauan Kritis Perbankan Syariah.Pustaka Darul Ilmi.Bogor.

Bungin, B., 2005. Analisis Data Penelitian Kualitatif: Pemahaman Filosofis dan Metodologis ke Arah Penguasaan Model Aplikasi, Penerbit PT RajaGrafindo Persada, Jakarta.

Chapra, M.Umar, 2000, Sistem Moneter Islam, Gema Insani, Jakarta.

Friyato.2010.Analisis Implementasi Pembiayaan Mudharabah Dan RisikoRisikonya (Studi Kasus Pada Bank BTN Kantor Cabang Syariah Malang). Malang: Thesis S2. Fakultas Ekonomi Universitas Brawijaya.

Fitri, Nina Surya. 2010. Implementasi Undang-Undang Nomor 2 Tahun 1960 Tentang Perjanjian Bagi Hasil Di Kabupaten Kampar Riau. Tesis. Semarang: Program Studi Magister Kenotariatan Universitas Diponegoro.

Harian Bisnis Indonesia, 20 Mei 2012

Indriantoro, Nur dan Supomo, Bambang. 1999. Metodologi Penelitian Bisnis: untuk Akuntansi dan Manajemen. Yogyakarta: BPFE.

Kuncoro, Haryo. 2002. Upah Sistem Bagi-Hasil Dan Penyerapan Tenaga Kerja. Jurnal Ekonomi Pembangunan Kajian Ekonomi Negara Berkembang. Hal:45-56.

Laffont, Jean-Jacques dan Matoussi, Mohamed Salah. "Moral Hazard, Financial Constraints and Sharecropping in El Oulja." The Review of Ekonomic Studies, Juli 1995, 62(3), 381-399.

Moleong, L. J. 2007. Metode Penelitian Kualitatif. Pt. Remaja Rosdakarya Offset: Bandung.

Muhadjir, N. 2007. Metodologi Penelitian Kualitatif. Rake Sarasin. Yogyakarta. 
Mulawarman, Aji Dedi.2009.Akuntansi Syariah Teori,Konsep dan Laporan Keuangan.Penerbit E.Publishing Company.Jakarta.

Nafik Hr, Muhamad. 2009. Bursa Efek dan Investasi Syariah. PT Serambi Ilmu Semesta.Jakarta.

Nurhayati,Sri \& Wasilah.2009.Akuntansi Syariah di Indonesia Edisi 2. Penerbit Salemba. Jakarta.

Sachiho, Arai W. 2008. Pembangunan Perkebunan Kelapa Sawit di Riau: Sebuah Tafsiran Seputar Pemberdayaan Petani Kebun. Komaba Studies in Human Geography. Vol.19 1-16.

Setyamidjaja,1993

Spradley. 1997. Metode Etnografi. Pengantar: Amri Marzali. Yogyakarta: Tiara Kencana.

Sugiyono. 2010. Metode Penelitian Kuatitatif, Kualitatif dan $R \& D$. Alfabeta: Bandung.

Sukoharsono, Eko G. 2006. Alternatif Riset Kualitatif Sains Akuntansi: Biografi, Phenomelogi, Grounded Theory, Ethnografi Kritis, dan Studi Kasus. Analisis Makro dan Mikro, BPFE Universitas Brawijaya, Malang, 230245.

2009. Refleksi Ethnografis Kritis: Pilihan Lain Teknik Riset Akuntansi. Jurnal Akuntansi dan Bisnis 4 (1): 91-109.

Syahpawi,2008. Prilaku Muamalah Budaya Melayu Dapat Dijadikan Sebagai Dasar Produk Perbankan Islam. Hukum Islam. Vol. VIII No.1 Juni 2008

Tarsidin.2010. Bagi Hasil Konsep dan Analisis.Lembaga Penerbit Fakultas Ekonomi Indonesia.Jakarta.

Thamrin, Husni. 2007. Etnografi Melayu Tradisi dan Modernisasi. Penerbit: Suska Press. Pekanbaru

Triyuwono, Iwan.2006. Akuntansi Syariah: Perspektif, Metodologi dan Teori. Rajawali Press.Jakarta.

Wikipedia, 2015 